\title{
The social dimension of global production systems: A review of the issues
}

Working Paper No. 25

\section{Susan Hayter}

Policy Integration Department

World Commission on the Social Dimension of Globalization

International Labour Office

Geneva

November 2004

Working papers are preliminary documents circulated

to stimulate discussion and obtain comments 
Copyright $($ International Labour Organization 2005

Publications of the International Labour Office enjoy copyright under Protocol 2 of the Universal Copyright Convention. Nevertheless, short excerpts from them may be reproduced without authorization, on condition that the source is indicated. For rights of reproduction or translation, application should be made to the Publications Bureau (Rights and Permissions), International Labour Office, CH-1211 Geneva 22, Switzerland. The International Labour Office welcomes such applications.

Libraries, institutions and other users registered in the United Kingdom with the Copyright Licensing Agency, 90 Tottenham Court Road, London W1T 4LP [Fax: (+44) (0)20 7631 5500; email: cla@cla.co.uk], in the United States with the Copyright Clearance Center, 222 Rosewood Drive, Danvers, MA 01923 [Fax: (+1) (978) 750 4470; email: info@copyright.com] or in other countries with associated Reproduction Rights Organizations, may make photocopies in accordance with the licences issued to them for this purpose.

ISBN 92-2-117036-5 (printed version)

ISBN 92-2-117037-3 (web version)

First published 2005

Cover:

The designations employed in ILO publications, which are in conformity with United Nations practice, and the presentation of material therein do not imply the expression of any opinion whatsoever on the part of the International Labour Office concerning the legal status of any country, area or territory or of its authorities, or concerning the delimitation of its frontiers.

The responsibility for opinions expressed in signed articles, studies and other contributions rests solely with their authors, and publication does not constitute an endorsement by the International Labour Office of the opinions expressed in them.

Reference to names of firms and commercial products and processes does not imply their endorsement by the International Labour Office, and any failure to mention a particular firm, commercial product or process is not a sign of disapproval.

ILO publications can be obtained through major booksellers or ILO local offices in many countries, or direct from ILO Publications, International Labour Office, CH-1211 Geneva 22, Switzerland. Catalogues or lists of new publications are available free of charge from the above address, or by email: pubvente@ilo.org

Visit our website: www.ilo.org/publns 


\section{The social dimension of global production systems: A review of the issues}

\section{Contents}

Foreword

Preface

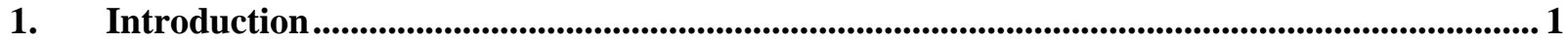

2. The globalization of production.................................................................................................. 1

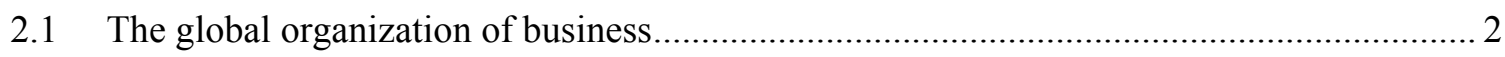

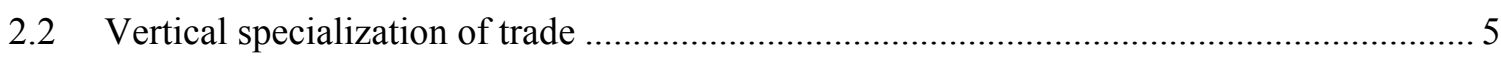

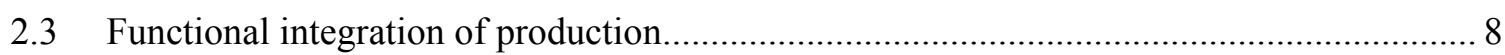

3. The social dimension - a review of the issues ................................................................................ 11

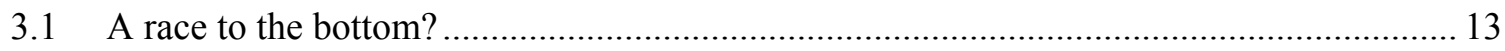

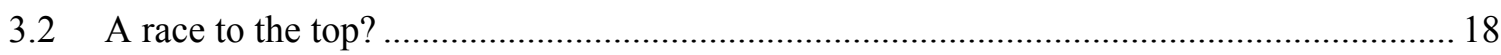

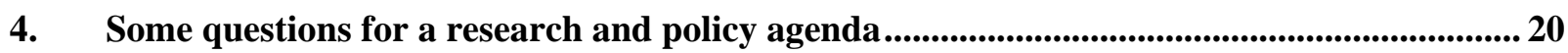

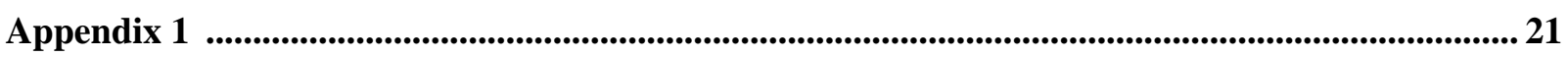

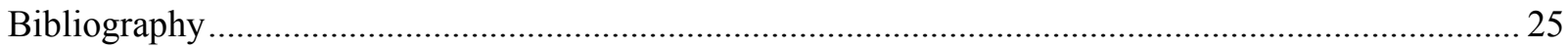




\title{
Foreword
}

In February 2002, the ILO established an independent World Commission on the Social Dimension of Globalization, co-chaired by President Tarja Halonen of Finland and President Benjamin Mkapa of Tanzania and comprising 26 eminent commissioners from a wide range of walks of life and different parts of the world, each serving in their individual capacity. Its broad goals were: to identify policies for globalization that reduce poverty, foster growth and development in open economies, and widen opportunities for decent work; to explore ways to make globalization inclusive, so that the process can be seen to be fair for all, both between and within countries; to promote a more focused international dialogue on the social dimension of globalization; to build consensus among key actors and stakeholders on appropriate policy responses; and to assist the international community forge greater policy coherence in order to advance both economic and social goals in the global economy.

The report of the World Commission, A fair globalization: Creating opportunities for all, was released on 24 February 2004. It is available on the Commission's website www.ilo.org/public/english/wcsdg/index.htm.

A secretariat was established by the ILO to support the Commission. Among other tasks, it compiled information and commissioned papers on different aspects of the social dimension of globalization. The aim was to provide the Commission with documentation and data on a wide range of options and opinions concerning subjects within its mandate, without committing the Commission or individual Commissioners to any particular position on the issues or policies concerned.

Material from this background work is being made available as working papers, as national and regional reports on meetings and dialogues, and in other forms. Responsibility for the content of these papers and publications rests fully with their authors and their publication does not constitute an endorsement by the World Commission or the ILO of the opinions expressed in them.

\author{
Gerry Rodgers \\ Director \\ Policy Integration Department
}




\section{Preface}

The Technical Secretariat to support the World Commission on the Social Dimension of Globalization first prepared a synthesis of ILO activities on the Social Dimension of Globalization (published as Working Paper No. 1 in this series). Documentation on the work and outcomes of other major commissions, an ideas bank, a database and knowledge networks of experts and social actors were subsequently developed. These networks have dealt with several topics, including: inclusion at the national level for the benefits of globalization to reach more people; local markets and policies; cross-border networks of production to promote decent work, growth and development; international migration as part of the Global Policy Agenda; international governance (including trade and finance); the relationship between culture and globalization; and values and goals in globalization. Gender and employment aspects were addressed throughout this work. The Reports on the Secretariat's Knowledge Network Meetings are available on the Commission's web site or in a special publication from the ILO (ISBN 92-2-115711-1).

During the course of these activities, a number of substantive background papers were prepared, which are now made available for wider circulation in the Policy Integration Department's Working Paper series (Nos. 16 to 38), as well as on the Commission's website.

Susan Hayter, an ILO Senior Policy Analyst who was on detachment to the Secretariat of the World Commission, argues that one of the defining features of the current phase of globalization is the emergence of global production systems. In contrast to earlier phases of globalization, economic activity is not only global in scope but also global in organization. The emergence of these global production systems has been one of the key drivers behind the increase in trade and FDI over the last twenty years.

From the mid-1980s on, falling barriers to trade and investment, cheaper transport and rapid technological advancements made it possible to break the production process up into distinct stages and locate these in different countries in order to take advantage of lower costs, the availability of raw materials and/or more favorable policy environments. Advances in management systems and new information and communication technologies (ICT) meant that these cross-border production lines could be coordinated on a global basis. The result has been the emergence of global production systems in many sectors. While these have been most pronounced in high-tech industries (electronics, semiconductors etc.) and in labour intensive goods (textiles, clothing and footwear), they are also becoming increasingly significant in services where software development, financial services and customer call services can now be supplied from different parts of the world.

The emergence of these production systems raises a number of questions in respect of the social dimension of globalization: what this means for work, the quality and quantity of employment, income and regulation of labour markets.

Her paper traces the emergence of these global production systems and highlights some of their key characteristics. It reviews the growing concerns about the impact of the globalization of production on employment, wages and working conditions in both developed and developing countries. It concludes by raising a number of questions for a research and policy agenda.

\section{Rolph van der Hoeven \\ Manager, Technical Secretariat \\ World Commission on the Social Dimension of Globalization}

November 2004 


\section{Global production systems and labour standards: A review of the issues}

\section{Introduction}

Many of the goods we consume today are likely to have come off a production line that stretches across borders, linking units of different sizes, levels of formality and technological capability. Services too can now be supplied from different countries around the globe, in real time, 24 hours a day. A key characteristic of globalization today is that the production of goods and services in many sectors is organized on a global basis. This evolution in the production system holds important implications for the social dimension for work, employment, income and working conditions.

This paper traces the emergence of these global production systems and highlights some of their key characteristics. It then reviews the issues that have arisen in respect of the social dimension of these global production systems. It concludes by raising a number of questions for a research and policy agenda.

\section{The globalization of production}

Contemporary analysis of globalization has tended to focus on the liberalization and expansion of world trade and Foreign Direct Investment (FDI), and the emergence of huge cross-border financial flows over the last twenty years (see Figure 1). Yet there were also other periods of history when quantitative increases in world trade and cross-border flows of capital facilitated international economic integration, such as the period preceding the First World War.

A distinguishing characteristic of the current phase of globalization is that economic activity is not only global in scope but also global in organization. From the mid-1980s on, falling barriers to trade and investment, cheaper transport and rapid technological advancements made it possible to break the production process up into distinct stages and locate these in different countries in order to take advantage of lower costs, the availability of raw materials and/or more favorable policy environments. Advances in management systems and new information and communication technologies (ICT) meant that these cross-border production lines could be coordinated on a global basis.

As a result, global production systems began to emerge in many sectors. While these have been most pronounced in high-tech industries (electronics, semi-conductors etc.) and in labour intensive goods (textiles, clothing and footwear), they are also becoming increasingly significant in services where software development, financial services and customer call services can now be supplied from different parts of the world. 
Figure 1 : Trade and net FDI inflows as percentage of World GDP, 1970-2001

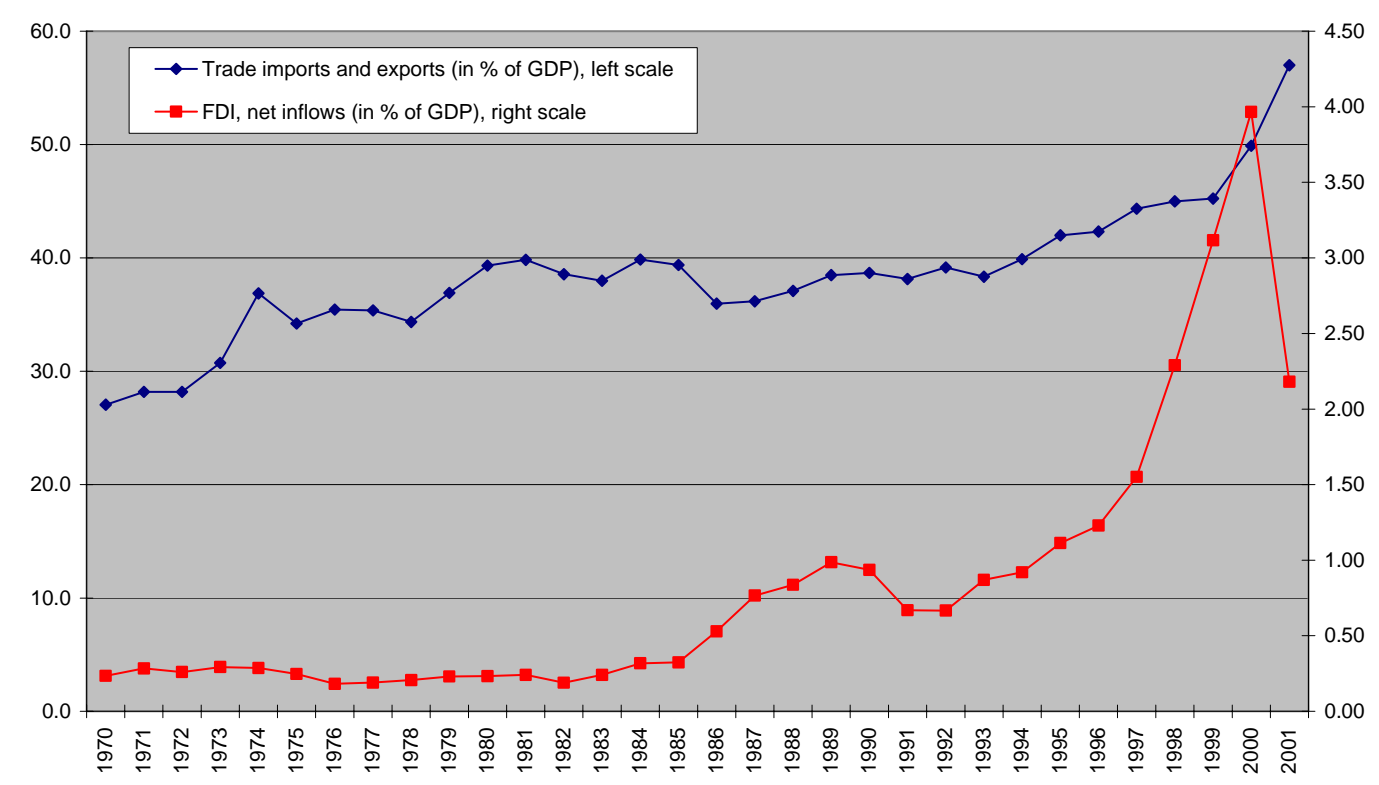

Source: ILO, World Commission Report 2004

This change in the way economic activity is organized produced a deeper and qualitatively different level of global economic integration (Gereffi, 2004). Of course a large percentage of production continues to be national or local for national and local markets, however a growing percentage of production is functionally integrated into global production systems for supply to global markets.

This section examines three features of this qualitative change that are unique to the current phase of globalization. The first is a change in the global organization of business, the second is a change in the structure of world trade and the third is the functional integration of global production.

\section{$2.1 \quad$ The global organization of business}

The steady expansion of Multinational Enterprises (MNE) and their related trade and investment activities transformed the face of industrial organization in the global economy. A number of international chartered trading companies had begun to emerge in the fifteenth century, such as the Hudson's Bay Company and the East India Company. While their economic activities were global, their raison d'être was the trade and exchange of finished goods and not international production.

It was only in the late nineteenth and early twentieth century that MNEs emerged as new actors in the global economy with production facilities located outside their home country (Dicken, 1998). By the end of the Second World War, MNEs had become key economic 
actors and played a critical role in rebuilding, and in many ways transforming, the postwar global economy. Today there are around 61000 MNEs with around 900000 affiliates in different countries around the world. Most MNEs are headquartered in the developed world. Of the top 100 MNEs (ranked by foreign assets for 2002), only 3 have their headquarters in a developing country. ${ }^{1}$

These MNEs played an increasingly prominent role in shaping the global economy. They are estimated to account for two-thirds of world trade and intra-firm trade, between MNEs and affiliates, is estimated to account for about one-third of world exports. As we will see in the next section, it is the way in which these MNEs have been organizing international production that accounts for much of the expansion of world trade and FDI over the last two decades.

\section{Industrial organization}

Why did firms internationalize production and become MNEs? Early theoretical explanations of internationalization in the industrial organization tradition focused on internationalization as a means by which firms strengthened their market power. ${ }^{2}$ Later writing stressed the role that internationalization played in enabling firms to reduce transaction costs by internalizing markets for intermediate products. ${ }^{3}$ Other writers combined these elements into an eclectic theory according to which, whether or not a firm internationalizes production would depend on the advantages of direct ownership (i.e. market power), the extent to which it is possible to reduce the cost of cross-border transactions such as the monitoring of quality by internalizing these transactions, and the extent to which the firm is able to use its market position to generate more profit by locating a value-adding activity abroad rather than having this supplied by an independent firm in that location. ${ }^{4}$

While there has been extensive empirical work on the determinants of foreign investment ${ }^{5}$ (i.e. the reasons that firms choose to invest in production capacity in one or other country), there has been very less research on the effect the internationalization of production has had on the contestability of global markets.

The question here is whether the internationalization of production has enabled firms to generate higher rates of return than they would have done had the same activity been undertaken at home or by an independent foreign firm. Has this led to greater concentration in global markets, and if so what are the implications for the distribution of the gains of globalization?

\footnotetext{
${ }^{1}$ Hutchison Whampoa Limited (Hong Kong, China), Cemex (Mexico), Samsung Electronics Co. Ltd. (Republic of Korea). UNCTAD, World Investment Report, 2004.

${ }^{2}$ See Hymer (1968), developed later by Caves (1971).

${ }^{3}$ See Buckley and Casson (1976).

${ }^{4}$ Otherwise expressed as an evaluation of the ownership advantages, internalization advantages and locational advantages, see Dunning (2000) for a review.

${ }^{5}$ See Hanson (2000) for a review.
} 
Measurement of global market concentration is a complex matter and there are important data limitations. A World Bank (2003) report reviewed studies of the top 50 MNEs (as published by Forbes) and concluded that global concentration had not increased during the 1990s. These studies used three measures, first, the percentage share of employment in the world labour force and in OECD employment, second, profits as a share of global and OECD savings, and third, sales in relation to global GDP.

One difficulty with these and other available measures of global concentration is that they do not reveal much about the concentration of market power in individual sectors. Nolan et. al. (2002) review published indicators of market share and show that for particular industries, market power has become increasingly concentrated between a few MNEs. They conclude that:

In the 1990s, [a] global business revolution produced an unprecedented concentration of business power in large corporations headquartered in the high income countries. ${ }^{6}$

This appears to be at odds with the common perception that globalization is associated with more competition. But, as Nolan et. al. (2002) point out, oligopolistic competition can be as intense as small-scale competition. They argue that even under these conditions, consumers across the world have benefited from lower cost, higher quality products.

Milberg (2004) presents evidence to refute claims that markets remain contestable despite the increased concentration of market power in the hands of a few showing that most developed country oligopoly industries (with the exception of Japan) have markups that are double those in competitive industries.

What is of concern is what this implies for the distribution of the 'gains of globalization' since this is likely to be highly uneven in a world of global oligopoly where most MNEs are headquartered in developed countries. In addition, this market structure also is likely to make it particularly difficult for enterprises in developing and newly industrializing countries to enter global markets today. What are the implications for people working in these global production systems, and for their jobs and wages changed? This is an issue we turn to later in the paper.

\section{Organizational structure and coordination}

The organizational structure of global business and coordination of their international production activities has also undergone transformation. Early MNEs relied on hierarchical forms of coordination and production was vertically integrated (within the boundaries of the firm). They used subsidiaries abroad to source raw material, tap low-cost labour and sell their products in relatively protected foreign markets (Vernon, 1971).

MNEs today no longer resemble the vertically integrated monoliths that early theorists such as Vernon (1971) described. The increased 'outsourcing' of non-core manufacturing and service activities, both domestically and abroad, has given rise to networked forms of organization and coordination. ${ }^{7}$ These networks include MNEs, small and medium sized firms in developed and developing countries, and production units in the informal economy (including home-based workers).

\footnotetext{
${ }^{6}$ Nolan et al. (2002) pg 91.

${ }^{7}$ For further analysis of this networked form of organization see Powell (1990) and Castells (1996). Gereffi et al. (2003) further categorize network forms further into modular, relational and captive types.
} 
The emergence of these 'production networks' does not imply that MNEs no longer exercise power and influence over production that has been outsourced. Studies of the global organization of industries show how global buyers explicitly coordinate a supply base, without owning production, transport or processing facilities. ${ }^{8}$ The Gap Inc. and Nike may be dressing North American consumers but they do not own any factories. By separating out the physical production of goods from the design and marketing stage of the production process, and retaining proprietary control over the design, distribution and marketing, they manage to retain de facto control over production (Gereffi, 1994).

The global organization of business today can be likened to a pyramid, made up of different types of firms, with different degrees of market power. At the top of the pyramid are MNEs such as Wal Mart, The Gap Inc. and Nike, most likely to be headquartered in a developed country. In the middle of the pyramid may be first tier suppliers, such as Li \& Fung or Esquel. At the bottom are smaller firms located in different parts of the world, some registered others not. The emergence of MNEs and change in the global organization of business has important implications for regulation and presents an important avenue of enquiry.

\subsection{Vertical specialization of trade}

A corollary to the change in the global organization of business - which involved a shift to networked forms of organization and coordination - is that intra-industry trade in intermediate inputs has increased. Economists refer to this as vertically specialized trade. ${ }^{9}$

From around 1945 onward, in a context of import substitution in developing countries and post-war reconstruction in developed countries, most FDI tended to be horizontal. Horizontal FDI involves the duplication of the entire production process in a different location to supply that foreign market. This type of FDI usually substitutes for trade because it replaces exports to that market with local production.

With the widespread liberalization of trade and FDI, a change in the development strategies and export propensities of newly industrializing countries in the 1980s and 90s, falling transport costs and rapid technological advancements, the cross-border economic activities of MNEs accelerated and diversified. ${ }^{10}$

\footnotetext{
${ }^{8}$ Gereffi (1994) distinguishes these buyer driven chains from producer-driven chains in which the MNEs retains research and design (R\&D) and final assembly, but outsources segments of production.

${ }^{9}$ See Hummels et al. (2001) for a review of the emergence of this concept.

${ }^{10}$ These now include inter-firm and intra-firm trade, greenfield investment, mergers and acquisitions (M\&As), strategic alliances (ranging from an arms-length contract to a joint venture) and electronic alliances (e.g. Business-to-Business exchanges or B2B). See OECD (2001).
} 
Today international trade and foreign investment are no longer viewed as substitute strategies for tapping into foreign markets. They are likely to be complementary elements of a global strategy to access lower-cost inputs, gain market power and supply domestic and foreign markets (See table 1). FDI flows may now also be 'vertical'. 'Vertical' FDI involves the investing in affiliates which only undertake parts of the production process, in locations where lower-cost intermediate inputs (labour, technology, commodities and/or intermediate goods etc.) and. This type of FDI is usually trade creating, because products at intermediate stages of production are shipped between affiliates. As a result, the link between trade and investment patterns is significantly stronger.

Table 1: Goods and capital flow in global production systems

\begin{tabular}{|l|l|l|}
\hline \multicolumn{1}{|c|}{ Sector } & \multicolumn{1}{|c|}{ Type of goods flow } & Type of capital flow \\
\hline $\begin{array}{l}\text { Low design, specification } \\
\text { requirement. (e.g. standard } \\
\text { apparel, electronics, toys) }\end{array}$ & $\begin{array}{l}\text { Arm's-length trade in } \\
\text { intermediate inputs and } \\
\text { assembled goods. }\end{array}$ & None \\
\hline $\begin{array}{l}\text { Low technological } \\
\text { requirement, high design } \\
\text { requirement. (e.g. non- } \\
\text { standard apparel, footwear, } \\
\text { electronics, services) }\end{array}$ & $\begin{array}{l}\text { Intra-firm trade and arm's- } \\
\text { length trade in intermediate } \\
\text { inputs and assembled goods. }\end{array}$ & $\begin{array}{l}\text { Some vertical FDI, mainly } \\
\text { technological or } \\
\text { knowledge-based. }\end{array}$ \\
\hline $\begin{array}{l}\text { High technological and } \\
\text { design requirement (e.g. } \\
\text { Automobiles). }\end{array}$ & Intra-firm trade & Horizontal and vertical FDI \\
\hline
\end{tabular}

Adapted from Milberg, W. 2004

With the acceleration and diversification of the investment and production related activities of MNEs, trade in intermediate inputs and their use in the production of goods for export, has become an increasingly significant feature of world trade.

Vertically specialized trade is not specifically measured in international trade data, with the exception of machinery and transport equipment. In a detailed study of the machinery and transportation equipment sector (SITC 7) Yeats (1998) finds that since the early 1980s, trade in parts and components for this group have grown faster than trade in finished goods. By 1995, trade in parts and components comprised about 30 per cent of the total exchange (components plus assembled goods), up from 26.1 per cent in 1978.

A closer examination of four main groups of intermediate inputs (parts for office and data processing machines, electrical switchgear, transistors and valves etc., and parts for motor vehicles) in the SITC 7 group (machinery and transport equipment) confirms that exports in these intermediate inputs have become increasingly significant, particularly for developing countries (See Table 2). 

Table 2: Exports of Intermediate Inputs for Machinery and Transport Equipment
(in billion US\$)

\begin{tabular}{|c|c|c|c|c|c|}
\hline & 1990 & 1995 & 2000 & 2002 & $\begin{array}{c}\text { Growth } \\
\text { Rate } \\
(\%)\end{array}$ \\
\hline \multicolumn{6}{|l|}{ World exports } \\
\hline Parts for office and data processing machines (SITC 759) & 48.2 & 91.6 & 150.7 & 48.2 & 7.5 \\
\hline Electrical switchgear (incl. relays, fuses, plugs)(STIC 772) & 35.3 & 64.2 & 91.0 & 35.3 & 7.4 \\
\hline Transistors, valves, etc. (STIC 776) & 59.0 & 172.7 & 284.6 & 59.0 & 10.9 \\
\hline Parts of motor vehicles (STIC 784) & 84.4 & 121.0 & 141.3 & 84.4 & 5.2 \\
\hline Sum $(759+772+776+784)$ & 226.9 & 449.5 & 667.7 & 226.9 & 7.67 \\
\hline \multicolumn{6}{|l|}{ Developed countries' exports } \\
\hline Parts for office and data processing machines (SITC 759) & 39.5 & 61.7 & 78.6 & 55.2 & 4.1 \\
\hline Electrical switchgear (incl. relays, fuses, plugs)(STIC 772) & 31.4 & 49.5 & 61.5 & 49.6 & 5.9 \\
\hline Transistors, valves, etc. (STIC 776) & 40.7 & 102.4 & 148.4 & 107.8 & 9.6 \\
\hline Parts of motor vehicles(STIC 784) & 75.6 & 110.3 & 120.3 & 116.3 & 5.0 \\
\hline Sum $(759+772+776+784)$ & 187.2 & 324.0 & 408.8 & 328.9 & 6.1 \\
\hline as $\%$ of SITC-7 exports (developed countries) & 7.7 & 9.5 & 10.4 & 9.9 & - \\
\hline \multicolumn{6}{|l|}{ Developing countries' exports } \\
\hline Parts for office and data processing machines (SITC 759) & 8.4 & 29.6 & 70.1 & 37.3 & 17.5 \\
\hline Electrical switchgear (incl. relays, fuses, plugs)(STIC 772) & 3.6 & 13.5 & 27.1 & 14.8 & 14.7 \\
\hline Transistors, valves, etc. (STIC 776) & 18.1 & 69.7 & 135.1 & 61.0 & 13.8 \\
\hline Parts of motor vehicles(STIC 784) & 6.3 & 9.0 & 16.6 & 13.2 & 8.4 \\
\hline Sum $(759+772+776+784)$ & 36.4 & 121.8 & 248.8 & 126.2 & 13.8 \\
\hline as \% of SITC-7 exports (developing countries) & 5.0 & 9.5 & 13.3 & 13.1 & - \\
\hline
\end{tabular}

Note: SITC refers to Standard Industrial Trade Classification (revision 2). See Country groupings from UNCTAD 2003. Growth Rate is computed as average annual percentage change from 1990-2002.

Source: UNCTAD (2003), CD-ROM

Total exports for these intermediate inputs grew at an average annual rate of 7.67 per cent between 1990 and 2002, compared to a growth rate of 5.9 per cent for total world exports over the same period. For developing countries exports in these intermediate inputs grew at an annual average of 13.8 per cent between 1990 and 2002, far exceeding the growth rate for total developing country exports of 8.5 per cent over the same period

A number of studies also point to the growing significance of vertical intra-industry trade. Hummels et. al (2001) estimate that vertical trade has grown by almost 30 per cent and accounts for one-third of the growth in world trade over the last 20 to 30 years. Borga and Zeile (2002) estimate that in 1999, 92.4 per cent of exports by U.S. parent firms to their manufacturing affiliates were inputs for further processing. ${ }^{11}$ While there has been some debate about the methodologies and measurements used, the broad conclusion that emerges from these studies is that vertically specialized trade, in the context of global production, has been driving the growth in world trade.

One of the key factors influencing the growth of this type of trade is the existence of policy incentives such as regional preferential agreements and export processing zones (EPZs)

\footnotetext{
${ }^{11}$ See Campa and Goldberg (1997) for Canada, Japan, United Kingdom and the United States.
} 
(Venables, 2002 and Yi, 2003). Over the years, the number of EPZs, which import intermediate inputs and process them for export, has dramatically increased (see Table 3).

Table 3: Estimates for the Proliferation of Export Processing Zones

\begin{tabular}{|l|r|r|r|r|r|}
\hline & \multicolumn{1}{|c|}{1975} & \multicolumn{1}{|c|}{1986} & \multicolumn{1}{|c|}{1995} & \multicolumn{1}{c|}{1997} & \multicolumn{1}{c|}{2002} \\
\hline $\begin{array}{l}\text { No. of Countries } \\
\text { with EPZs }\end{array}$ & 25 & 47 & 73 & 93 & 116 \\
\hline No. of EPZs & 79 & 176 & 500 & 845 & 3000 \\
\hline $\begin{array}{l}\text { Employment } \\
\text { (millions) }\end{array}$ & 0.8 & 1.9 & n.a. & 22.5 & 43 \\
\hline
\end{tabular}

Source: ILO 2003

The growing significance of vertically specialized has implications for trade theory and raises important questions about the prospects for development, employment and incomes. ${ }^{12}$ This opens up an important research and policy agenda.

\subsection{Functional integration of production}

The process by which production has been broken up into distinct segments and outsourced to distant locations has been variously referred to in the economic literature as the "slicing up of the value chain" (Krugman, 1995), the "disintegration of production" (Feestra, 1998) or "fragmentation" of production (Arndt and Kierzkowski, 2001). This emphasis in the economic literature on the unbundling or unraveling of production belies an important change that has been underway in the global economy since the mid-1980's involving the functional integration of geographically dispersed production activities (Dicken, 1998).

Writing in the early 1980s, Sabel and Piore (1984) identified historical breaks in the path of a given system of industrial technology (i.e. production system) which they called 'industrial divides'. The first industrial divide occurred in the nineteenth century with the transition from craft-based systems to a mass production system. The beginning of the age of mass production can be traced to Henry Ford's famous Model T in 1913, built from parts on a moving assembly line - a form of work organization known as Taylorism. They argued that firms would need to move beyond mass production and transform their production systems if they were to survive and prosper. This second industrial divide entailed a shift to a post-fordist production system characterized by the decentralization of decision-making, small scale production and 'flexible specialization'.

What was not evident at the time that they were writing is that rapid technological and the emergence of global production systems in many sectors provide the very type of "flexible specialization" envisaged by those writing about a post-fordist production regime.

\footnotetext{
${ }^{12}$ For a discussion of the implications for trade theory and policy, see Milberg (2004).
} 
The production of many goods and services today are organized along a cross-border production chains ${ }^{13}$ which integrate the distinct value-adding activities of production units in different locations into a unitary global production system. This has created a global "just-in-time" system that gives MNEs the flexibility to alter production in the face of fluctuations in market demand with minimal inventory cost. In this new business model MNEs are able to retain decisions about product design and quality, but download risk and uncertainty to firms further down the production chain, in which they (often) have no equity stake. Intense competition in intermediate inputs at the bottom of the production chain places lead firms in a powerful negotiating position and they are often able to secure short production runs to meet the changing demand from producers further down the supply chain.

An important stream of literature has been analyzing this global integration of distinct production segments into unitary global production systems in the different sectors. The analytical framework that has emerged from this literature is known as Global Value Chain analysis (GVC). GVC draws on Porter's (1985) concept of a 'value-chain' which was used to describe a set of discrete value-adding stages performed by the firm during a product's journey from conception, assembly and packaging to advertising and sale. It links this to the industrial organization literature, which as we have seen in the previous section, provides important insights on new actors in the global economy and the exercise of power in global markets. By bringing these two schools of thought together, the GVC literature provides insights into how the value-adding stages, being carried out in different countries, are functionally integrated into a unitary global production system. It shows the different points at which lead firms are able to exercise control and govern other (dependent) firms in the global supply chain. ${ }^{14}$

It is useful to make a distinction between the concept of a 'global value chain' and a 'global supply chain'. Although they are used interchangeably, the term 'global valuechain' is used to describe the functional integration of the value-adding stages located in different countries from conception to sales and after sales within a global production system (see Figure 2 and Figure 3). It is a useful analytical tool with which to analyze the structural characteristics of a particular global production system. The term 'global supply chain' is used to describe the supply of inputs from different locations, irrespective of the nature of the value adding activity being performed at each stage in the chain.

\footnotetext{
${ }^{13}$ The production chain is 'a transactionally linked sequence of functions in which each stage adds value to the process of production of goods and services' Dicken (1998, pp 7).

${ }^{14}$ See Gereffi et. al. 2003 for an analytical framework and also http://www.ids.ac.uk/globalvaluechains/.
} 
Figure 2. The global value chain for product components

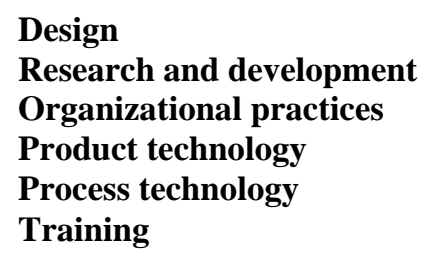

Design

Research and development Organizational practices

Product technology

Process technology

Training

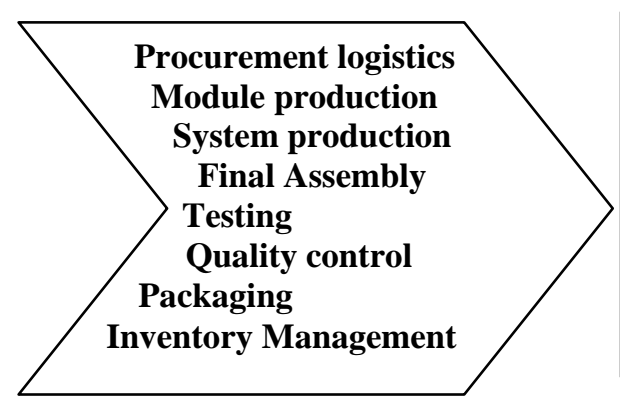

Distribution logistics

Wholesale retail

Retail sales

Advertising

Brand management

After-sales service

Source: UNCTAD, World Investment Report, 2002a

Figure 3. The global supply chain in the clothing and textile sector

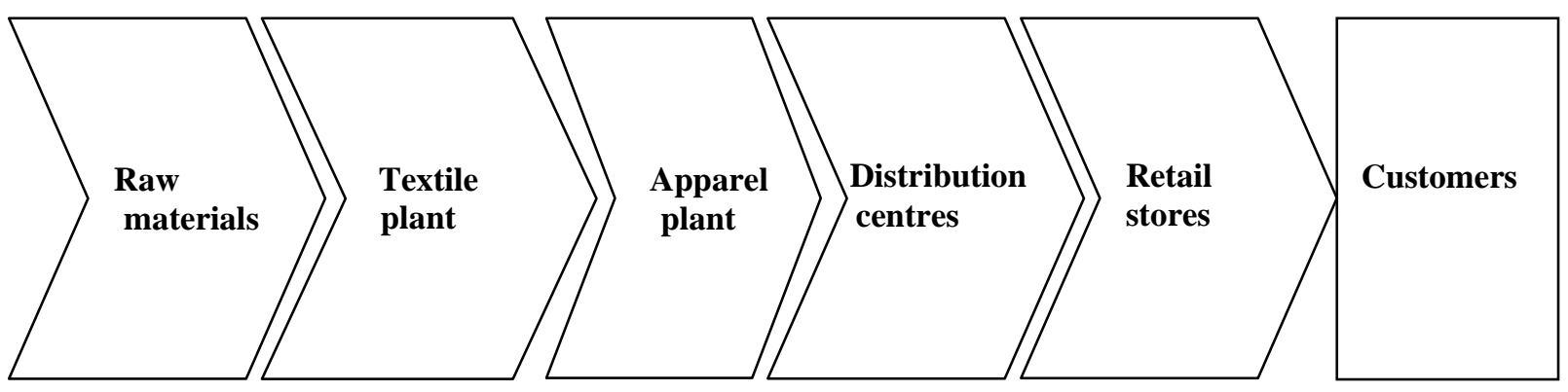

Source: Adapted from Nordås, 2004

GVC analysis has generated a number of empirical studies in different sectors. These illustrate the structures and configurations that exist in the different global sectors. They show the point in the global value chain at which production is being outsourced, and the different ways in which lead firms coordinate and integrate these discrete production segments (see Appendix 1 for detailed review of different global sectors).

A review of these different global production systems suggests that there are some common trends and features. The first is the growing significance of new global intermediaries or 'mid-tier suppliers', such as Li \& Fung in apparel and Celestica in the electronics sector, and the increasing power these firms now exercise in markets for intermediate inputs (Gereffi et.al. 2003). Second, is the growing propensity to modularize the assembly of intermediate manufactured inputs, allowing for the development of highly standardized linkages in the assembly of subcomponents (Sturgeon, 2002). For example first-tier suppliers in the automobile sector have shifted to producing and installing complete units (e.g. dashboards, seats, brake-axle suspension etc) rather than individual components. These first-tier suppliers now source relatively standardized sub-components from second-tier suppliers. Third, is the growing tendency to outsource business process services such as accounting and customer call services, in addition to assembly functions (Dossani and Kenney 2004). 
The literature on global value chains also provides important insights into the path firms follow as they move up the global value chain into less-labour intensive and more profitable knowledge intensive activities. ${ }^{15}$ It sketches an upgrading trajectory from simple assembly - to original equipment manufacturing involving a broader range of manufacturing functions (or 'full package' production) - to original design manufacture in which the firm takes on part of the design process in collaboration with the buyer - to original brand manufacture where the firm produces and markets under its own brand.

Many of the first-tier suppliers in East Asia today gained entry into global production systems through the labour-intensive assembly of imported inputs. They developed the capability to interpret designs, make samples, source the needed inputs, monitor quality, and guarantee on-time delivery. In this way they were successful in 'moving up the valuechain' into more integrated full-package supply. Some have moved beyond this to original brand manufacturing and are producing their own branded merchandise for domestic and foreign markets (Gereffi, 2002).

There is very limited analysis in the global value chain literature of how the integration of production and configuration of different global production systems has affected jobs, working conditions and wages. ${ }^{16}$ What are the implications for social policies aimed at creating employment, protecting the most vulnerable and improving income and working conditions? This suggests an important area for future research.

\section{The social dimension - a review of the issues}

The issues which emerge in the context of global production systems mirror the debates and concerns about the social impact of globalization - some see the glass as half empty others see it as half full.

On the one hand, the emergence of global production systems is considered to have created significant opportunities for some developing countries to integrate into the global economy. A number of low-income countries emerged as major exporters of manufacturers. This is considered to have had a positive effect on employment and wages in the manufacturing industries of some of these countries. ${ }^{17}$

Where domestic subsidiaries were integrated into global production systems through FDI, this had positive employment effects in some countries and provided opportunities for local firms to absorb new technologies and develop the skills needed to compete in global markets (Moran, 2001). The working conditions in affiliates are repeatedly cited as better than those in the domestic economy (Hanson, 2001).

\footnotetext{
${ }^{15}$ For example see Gereffi et al. (2003), and Humphrey and Schmitz (2002); For specific sectors see Gereffi and Memedovic (2003) for apparel and Humphrey and Memedovic (2003) for automobile.

${ }^{16}$ With the exception of work undertaken by the ILO Institute on global production systems and labour markets (see http://www.ilo.org/public/english/bureau/inst/papers/confrnce/gps.htm) and Lund and Nicholson 2004.

${ }^{17}$ For China, India and Malaysia, the growth of manufactures trade accelerated the growth of manufacturing of employment (Ghose 2003).
} 
The globalization of production is also believed to have increased employment and wage prospects for women in manufacturing industries in developing countries (Barrientos et al., 2004). The rapidly expanding global production system in the financial sector now also employs a high proportion of female workers in these countries, as do the telecommunications, information processing and tourism industries.

On the other hand, there has been growing concern about the impact of the globalization of production on employment, wages and working conditions in both developed and developing countries. There are a number of issues.

First, is concern that the growth in manufactures trade between developed and developing countries (in the context of global production) is the cause of the growing inequality between high-skilled and low-skilled workers in developed countries.

Second is concern over the perceived transfer of 'good' low-skilled manufacturing jobs in developed countries to developing countries. The issue here is not only about the loss of jobs in developed countries, but also that these have been replaced with 'bad' jobs in 'sweatshops' producing for export in developing countries. This led to considerable controversy and allegations of 'unfair trade' and 'social dumping'. There is now also growing concern that this is not limited to low-skilled jobs and that even skilled jobs in developed countries are being transferred as a result of the outsourcing and offshoring of services.

Third is a concern that competitive bidding between developing countries to attract FDI in the context of global production sharing is inducing them to offer unnecessary concessions on environmental and labour regulation and that this is fuelling a 'race to the bottom' in labour standards. There are particular concerns about the 'loose' regulatory framework for social and employment rights in EPZs and the widespread violation of workers' rights in these zones, particularly freedom of association. This, it is argued, has resulted in exploitative labour practices, including excessive working hours, discrimination and sexual harassment, and unsafe and unhealthy working environments. ${ }^{18}$

Related to this is a concern that MNEs are abusing their market power, threatening to disinvest or pull a production contracts in order to secure the most favorable conditions in developing country labour markets. This it is feared is placing downward pressure on wages and working conditions and undermining the bargaining position of trade unions, and of national employers' organizations as an interlocutor between national business interests and the State. ${ }^{19}$ This challenge to national regulation, it is argued, has been compounded by the orthodoxy on the deregulation of labour markets which dominated development thinking in the 1980s and 1990s. Part of the response to this 'regulatory deficit' has been demand for new international regulatory frameworks such as clauses on labour standards in bi-lateral trade agreements. Some argue that these do not go far enough to protect workers. Others see them as no more than protectionist responses to competition from low-wage countries.

Fourth, while participation in global production systems has been an important means for developing countries to integrate into the global economy, there has been debate about the role this has played in the process of industrialization, in creating employment and in improving income and working conditions. There is also significant concern that the internal market structure within global supply chains is preventing firms in developing countries from 'moving up the value chain' into more profitable activities.

\footnotetext{
${ }^{18}$ See ICFTU (2004).

${ }^{19}$ See Oxfam (2004).
} 
Two important issues emerge. The first is whether trade and FDI in the context of global production is placing downward pressure on labour standards and the role that the new international regulatory frameworks play in stemming this pressure. The second is how countries, enterprises and workers can benefit from their participation in these global production systems in terms of development, the upgrading of firms and improvements in labour standards.

Thus moving beyond whether the glass is half empty or half full, this section asks first, whether there is something inherent in the structure of global production systems that is causing the glass to empty and second, whether there are structural features in global production systems that prevent the glass from filling up. These are important issues that deserve attention if we are concerned with a 'fair globalization that creates opportunities for all ${ }^{20}$.

\subsection{A race to the bottom?}

Is the structure and dynamics of global production systems such that there is downward pressure on labour standards? There are two issues to consider. The first is whether vertically specialized trade with low-wage countries in global production systems has placed downward pressure on labour standards in developed countries. The second is whether competition for exports and FDI is undermining labour market regulation and by so doing fuelling a 'race to the bottom' in labour standards. Related to this is the role that new public and private forms of regulation play in containing this downward spiral of regulatory competition.

Is vertical trade between developed and developing countries in these global production systems fuelling a race to the bottom?

There has been widespread concern that the increase in manufactures trade with developing countries (in the context of global production) is responsible for the deteriorating labour market conditions, both job losses and growing inequality, in manufacturing in developed countries.

There are two widely cited explanations in the academic literature for the fall in the wages of less skilled workers relative to high-skilled workers in developed countries through the 1980s and 1990s. The first is that skill-biased technological change increased the demand for skilled labour. The second is that trade with low-wage countries depressed the demand for low-skilled labour in developed countries. Of the two explanations, technological change and the use of computers is widely held to be the dominant explanation for the rise in inequality. ${ }^{21}$

\footnotetext{
${ }^{20}$ See ILO, A Fair Globalization: creating opportunities for all, Report of the World Commission on the Social Dimension of Globalization (2004).

${ }^{21}$ See Krugman (1995, 2000), Feenstra and Hanson (1999) and Slaughter (1998). See also Wood (1994, 1995) for a dissenting view. For a comprehensive review of the literature on the relative influence of 'trade versus technology' on wages see Acemglu (2002).
} 
Feenstra and Hanson (2001) survey this literature on 'trade versus technology' and present a contrary view. They argue that most studies ignore the globalization of production and rise in the trade of intermediate inputs. While the introduction of computers has played an important role, foreign outsourcing and trade in intermediate inputs has been more closely associated with increases in the relative wage of skilled wages than was previously thought. The question of how the globalization of production (and vertical specialization of trade) has affected industry structure and the demand for labour in developed and developing countries remains an important question on the research and policy agenda, particularly in light of the growing propensity to outsource business process services.

The emergence of global production systems did create employment in some populous developing countries such as China, India and Malaysia. For countries in Latin America such as Brazil, the employment effects were not so favourable. Yet the net employment created in developing country manufacturing industries has been larger than the net employment loss in developed countries (Ghose, 2003).

The issue is that much of the employment created in these developing countries is outside of the regulated economy and is thus considered to be of inferior quality. While these jobs are arguably of better quality than other jobs in the unregulated economy and/or in the agricultural sector where many previously worked, these workers remain vulnerable and unprotected. In addition they face considerable insecurity as labour turnover in both the regulated and unregulated economy tends to be high. A key policy question is how the quality of these jobs can be improved, how to facilitate a shift from the informal to the formal economy, and the role that labour market institutions play in this process.

Another issue relates to the process of structural change that has been underway in developed countries, involving a decline in the proportion of manufacturing employment in total employment which accompanies processes of deindustrialization. While this is broadly considered to be an indicator of success and of advanced economic development, this is of little consolation to low-skilled workers who have experienced considerable economic hardship as a result of this economic adjustment. Not all have benefited from jobs created in the services sector. Against this backdrop of growing job insecurity are fears that this is not a benign phenomenon related to economic progress. Jobs in services are now also being outsourced and off shored.

There has been limited research on the evolution of the global production system in services and the employment effects in developed and developing countries. This is clearly an important area for future research. The process of structural change underway also raises the issue of adequate adjustment policies to assist displaced workers. This is an important issue since the political economy related to this process of structural change in developed countries could foreclose opportunities for economic growth and improvements in labour standards in both developed and developing countries alike.

\section{Is regulatory competition between countries fuelling a 'race to the bottom'?}

To recap, the issue here is whether competition for exports (in intermediate goods) and for FDI in the context of global production is placing downward pressure on labour standards. There are two ways of looking at this issue. The first is whether countries with lower labour standards have had better export success than countries with higher labour standards and are attracting more FDI. If this is the case, then there may be something inherent to global production systems that is fueling a 'race to the bottom'. A second way of looking at this issue is to assess the actual behavior of the actors (both governments and MNEs), does regulatory competition indeed exist and what might appropriate policy responses be? 
In examining the issues it is worth bearing in mind that lower labour standards tend to reflect lower levels of labour productivity and do not mean lower unit labour costs for investors or comparative advantage in trade. ${ }^{22}$ Studies on core labour standards show that there is no evidence that foreign investors favor countries with lower labour standards or that these countries have had better export performance. ${ }^{23}$ What these studies tell us is that lower labour standards, particularly core labour standards, are not a determinant of FDI or of export competitiveness.

Unfortunately these studies shed little light on the behavior of governments seeking to attract much needed investment and increase their export competitiveness, or on that of MNEs seeking out the most favorable business environment.

Where governments believe that regulatory discounts on labour standards (not only core standards) are an important part of an incentive package to attract foreign investors, they may delay adopting measures to improve these standards. For example, governments who believe that depressed wages are an important precondition for investment and/or necessary to increase earnings from exports, may delay the introduction of minimum wage legislation or inhibit attempts by unions or workers to increase wages. Economic analysis has distinct limitations when it comes to assessing this type of regulatory competition.

The rapid expansion of EPZs with fairly loose regulatory frameworks (either due to exemptions from labour law, not enforcing labour law or ensuring 'union free' zones) suggests that many policy makers in developing countries do believe that the suppression of wages (and trade union activities) and weak regulation of labour markets are necessary conditions for investment, export competitiveness and development. There is also limited evidence for Eastern Europe that shows that investors are seeking out countries with more flexible labour markets relative to those in their home country, based on measures of collective dismissals, the length of the notice period and severance pay (Javorcik and Spatareanu, 2004).

In light of the potentially negative consequences of these policies on workers and on longer-term development, there is need for research to establish the extent of this policy competition and impact of EPZ type policies on labour standards and development.

Since investment incentives are not always transparent, there is also always a danger that some type of "beggar-thy-neighbor" policy competition will emerge, reducing the benefits from investment for host countries as a whole and possibly also placing downward pressure on labour standards. ${ }^{24}$

\footnotetext{
${ }^{22}$ Cross-country variation in wages tend to relate to cross-country variation in labour productivity and so there is little systematic cross-country variation in labour unit costs. See Ghose (2003) for review of issues and studies.

${ }^{23}$ OECD (2000), Brown (2001), Kucera (2001) and Kucera and Sarna (2004). See latter for review of other available studies.

${ }^{24}$ See Oman (2000) for discussion.
} 
International collective action may be necessary to prevent a situation in which countries seeking to attract much needed investment are be pitted against one another, with negative consequences for workers and for development. The question of whether or not there should be an international policy framework for investment has been a particularly contentious issue in international policy debates. Yet there is undoubtedly a need for greater transparency in investment incentives if the potential for negative policy competition is to be contained. The question of a development friendly international investment framework remains an important item on the international policy agenda.

What role do the new regulatory frameworks play in stemming a "race to the bottom?"

There was growing concern during the 1990s that globalization was eroding labour standards and that traditional forms of regulation (such as national systems of industrial relations and labour law) were no longer sufficient in a context in which markets, market actors and production systems transcended national boundaries. This governance deficit triggered social demands for new forms of global governance (Gereffi and Mayer 2004).

Against the backdrop of the ILO Declaration on Fundamental Principles and Rights at Work in 1998 ( ILO 1998), a range of new regulatory frameworks emerged at the global level with specific provisions on core labour standards.

First are public frameworks, such as measures in bilateral and regional trade agreements and in the variety of public frameworks that support FDI. The latter include bilateral and regional investment treaties, overseas investment insurance (e.g. Multilateral Investment Guarantee Agency, World Bank) and the instruments and policies development finance institutions use in their the private sector funding. ${ }^{25}$

Second are private frameworks, such as the code of conduct regime that grew out of the broad corporate social responsibility movement in 1990s and framework agreements between Global Union Federations and MNEs, which are now estimated to cover some $2,962,850$ employees. $^{26}$

These new regulatory frameworks at the global level complement and draw on other international frameworks such as the OECD Declaration on International Investment and Multilateral Enterprises and the ILO Tripartite Declaration of Principles concerning Multinational Enterprises and Social Policy. ${ }^{27}$

The question that emerges is what role these new frameworks play in stemming any downward pressure on labour standards that might exists and in improving incomes and working conditions in global supply chains. The issue of how to improve labour standards while at the same time promoting development is a longstanding one and has led to allegations that those efforts to curb the abuse of labour rights reflect protectionist sentiments rather than genuine concerns for global social justice.

\footnotetext{
${ }^{25}$ See Polaski (2004a) and Penfold (2003) for a detailed review of these instruments.

${ }^{26}$ See Steiert and Hellmann (2004).

${ }^{27}$ See www. oecd.org and www.ilo.org.
} 
There is a growing body of literature on the different ways in which these new forms of governance are supporting improvements in labour standards in different countries. ${ }^{28}$ However what is absent from this discourse at present is a link to the development literature, which made significant progress during the 1990s in understanding the role that institutions (including laws, industrial relations systems etc.) play in the development process.

Low labour standards in developing countries are generally associated with dualistic labour markets, unemployment and underemployment. Any improvement in labour standards will need to entail an increase in regular employment and shift from the informal to formal economy.

Governments in many developing countries that are politically willing to implement international labour standards may be hampered in their efforts by underdeveloped and/or weak regulatory capacity. Yet even in those instances where the necessary administrative capacity and resources do exist to enforce regulation, this would still not be sufficient to facilitate the necessary change in the employment structure. At best these regulatory interventions will benefit a small segment of the workforce (registered workers in the export sector), at worst may have the unintended consequence of driving more workers into the unregulated sector, thus fuelling a 'race to the bottom'.

What is needed is both an increase in regular wage employment and the development of the appropriate institutional capacity to regulate labour markets, including statutory regulation and systems of industrial relations, in a manner that also has meaning to workers in the informal economy. ${ }^{29}$

There is general agreement that these new regulatory frameworks can have a positive effect on labour standards. However the degree to which these new forms of governance support sustainable improvements is likely to depend on the extent to which they are able to provide economic opportunities (e.g. access to markets which may have favorable employment effects) and the necessary incentives and support for the development of the appropriate institutional capacity to regulate labour markets (e.g. through technical assistance).

There is a danger that international monitoring efforts associated with these new international regulatory frameworks will merely replace already weak government capacity, rather than support the development of appropriate institutional capacity to regulate labour markets. As a result, improvements in labour standards are likely to be short-lived, observed only for the period during which resource intensive monitoring is present, and benefit a small segment of the workforce. This raises important issues for a research and policy agenda on the way in which these new regulatory frameworks can best support sustainable improvements in labour standards.

\footnotetext{
${ }^{28}$ For example see Harrison (2004) for Indonesia, Polaski (2004b) for Cambodia. For more general discussion see Elliot and Freeman (2003) and Sabel, O’Rouke and Fung (2000).

${ }^{29}$ See Ghose (2003) for discussion on improving labour standards in a developing economy.
} 
Many developing countries see participation in the labour intensive stage of production in these global production systems as the most direct route to being integrated into the global economy. They hope that this will fuel a virtuous process of development involving the upgrading of production and exports (from more labour-intensive to less labour-intensive and more technology-intensive goods) and improvements in labour standards.

As noted earlier, these global production systems did provide significant opportunities for growth and industrialization in a number of developing countries. Some East Asia newly industrialized countries (NIEs), including the Republic of Korea, Hong Kong (China), Singapore and Taiwan Province of China, were able to upgrade their production capacity into higher value-added manufacturing activities and shift their export structures into medium and high-technology manufactures (UNCTAD, 2002b). Participation in these global production systems provided an important channel for the transfer of technology and associated learning processes, which in turn fuelled productivity. These countries experienced a virtuous cycle of economic development in which leading industrial sectors emerged, along with related technological and social capabilities, in a context of overall structural change and an increase in the share of manufacturing in total employment. This in turn supported improvements in labour standards.

This has not been the experience of all countries participating in these global production systems. There has been a particularly striking difference between the performance of these East Asian NIEs and many Latin American countries. While some countries in Latin America exhibited strong performance in manufacturing exports (associated with global production) this was accompanied by a declining share in manufacturing value-added (UNCTAD, 2002b). Participation in these global production systems did not fuel a virtuous process of accumulation, productivity growth, and structural change. Even in countries where the export structure did change (toward higher-tech products) this was not accompanied by concomitant growth in productivity or improvements in manufacturing value-added. $^{30}$ Many countries which sought to improve their international competitiveness, or at a minimum retain their market share, in a context in which there were no improvements in labour productivity, appear to have resorted to wage suppression and/or sharp depreciations. The level of wages has fallen in most Latin American countries (UNCTAD, 2003).

UNCTAD (2003) argues that the reason these countries were not able to benefit from their participation in global production systems is that the policy reforms in Latin America in the 1980's failed to create the conditions needed to fuel the process of capital accumulation and technological change needed to restructure the economy.

\footnotetext{
${ }^{30}$ A note for non-economists, value-added here is taken to mean the sum of wages, raw materials and profits and should not be confused with the notion of 'value' in the literature on global value chains which refers specifically to the nature of the production process.
} 
Another factor is the terms of their participation in these global production systems. The East Asian NIEs had all developed before other developing countries began to shift their emphasis to export oriented production. ${ }^{31}$ Low barriers to market entry for the labourintensive stage of production enabled more and more developing country producers to enter markets for assembly of intermediate goods. As a result, competition for this stage of production intensified placing downward pressure on prices. Firms involved in intermediate labour-intensive assembly found themselves producing and exporting more and more, but receiving less and less return on these exports. ${ }^{32}$

One option was for these producers to upgrade into the more profitable stages of the global value chain. However the upgrading trajectory is not as straightforward as suggested in some of the GVC literature. Firms that do attempt to upgrade and move into more knowledge intensive activities often face barriers to as they attempt to enter markets further up the value chain, ranging from the anticompetitive practices of MNEs to tariff escalation with the degree of processing and product standards (Humphrey, 2004).

For apparel producers, the worsening terms of trade for labour-intensive exports at the bottom of global supply chains is now compounded by increased competition from large and populous low-wage countries such as China with the phasing out of quota's under the Multi-Fibre Agreement.

The market structure in global industries is also an important consideration for the development prospects of these firms. Producers (in developing countries) risk becoming dependent on a smaller pool of buyers, who are able to exert more market power by virtue of concentration in global industries. They may face demands to deliver against evershorter production deadlines for the same return, in a context of intense competition from suppliers in other countries. These factors serve to further undermine their market position.

The effect of this internal market asymmetry - a concentration of market power at the top of global value chains and excess production capacity at the bottom - raises important questions about the distribution of the gains of the globalization of production. ${ }^{33}$ The issue of how and where 'rent' (profits earned in excess than would have been the case under conditions of perfect competition) is generated in the internal markets of these global production systems and the implications for development, income and working conditions, presents an important research and policy agenda.

\footnotetext{
${ }^{31}$ Note these successful industrializers also pursued development strategies predicated on export promotion, conditional subsidies and protected domestic industries that have since fallen out of vogue and are no longer permissible under global trade rules (Amsden, 2001).

32 Economists refer to this phenomenon as "immiserising growth", essentially an increase in economic activity and expanded exports but a decline in overall returns due to falling prices (Kaplinsky and Morris, 2002). See also UNCTAD, 2002b.

33 For discussion of distributional issues and rent see Kaplinsky (2000), Kaplinsky (2004) and Brown et al. (2002).
} 


\section{Some questions for a research and policy agenda}

The premise of this paper is that a unique characteristic of the global economy today is the emergence of global production systems. The global organization of production accounts for much of the expansion in trade and FDI. The functional integration of production activities in different locations has produced a deeper level of global economic integration than that which occurred in previous phases of globalization. This has important implications for the social dimension of globalization: for work, employment, income and working conditions.

(i) A review of the issues suggests a number of important items for a research and policy agenda on the social dimension of global production systems:

(ii) The growing body of literature on global value chains analyses the structure of these global production systems in the different sectors, the way in which global production is governed and the upgrading trajectory firms take as they 'move up the value chain'. There has been limited analysis of how this is impacting on work, and the quantity and quality of employment. How does the structure of these production systems affect employment, income and conditions of work at different points in the global value chain? What are the implications for social policies aimed at creating employment, protecting the most vulnerable and improving income and working conditions?

(iii) How has the globalization of production (and vertical specialization of trade) affected industry structure and the demand for labour in developed and developing countries? Related to this is the question of the development of adequate adjustment policies in developed countries, and in developing countries the development of labour market policies and institutions that can improve the quality of employment.

(iv) Most analytical work to date has focused on manufacturing. Global production systems are also emerging in the service sector (e.g. in the Finance industry or in Telecommunications). In addition, there is a growing tendency to outsource business process services, such as accounting and customer call services, in traditional manufacturing industries. What is the impact on employment and income in developed and developing countries?

(v) Are governments engaging in policy competition to attract investors and what is the nature of the regulatory discounts that are being offered? What is the impact of EPZ policies on labour standards and longer-term development? What international policy frameworks could stem the potential for downward pressure on labour standards and promote greater transparency of incentives?

(vi) What opportunities are there to promote international labour standards in these global production systems? How can the new regulatory frameworks that are emerging at the global level best support sustainable improvements in labour standards and longer-term development?

(vii) How can countries, enterprises and workers benefit from participation in global production systems, in terms of development, the upgrading of firms, and improvements in labour standards? What is the role of technological development? How can firms overcome potential barriers to upgrading?

(viii) Where is rent being captured in these global production systems and what impact is this having on the distribution of income and prospects for development? What are the policy implications? 


\section{Appendix 1}

\section{Apparel and footwear}

In labour-intensive consumer goods sectors such as apparel and footwear, the lead MNE (either a retailer or designer) specifies the design and quality of the product and then outsources all of the production. Lead MNEs retain considerable leverage either as a result of their oligopoly power (e.g. J.C.Penny, Wal Mart) or their control over brand-name and product design (e.g. Nike). Global production is organized and coordinated in a number of different ways in this sector.

MNEs may establish an office abroad, enabling the company to closely monitor production and supply international markets directly, and be in a better position to negotiate with textile suppliers on quality and price. Direct sourcing is considered to have the advantage of cutting out intermediaries while reducing production lead times and allows for better control of product quality and contract compliance.

Alternatively, brands may supply intermediate inputs (cut fabric, thread, buttons etc.) to producers, traditionally located in EPZs, for assembly, who then export the assembled product back to the brand. Those involved in assembly may in turn subcontract to smaller enterprises working in the informal economy. This type of value-chain is typically positioned to take advantage of reciprocal or regional trade agreements (where goods can be re-imported with a tariff charged only on the value added by foreign labour).

Another configuration is one in which brand marketers and retailers rely on first tier suppliers (such as Li \& Fung or Esquel) to source globally from their own and subcontractor factories. These may be located in Africa, Asia and Latin America. Since trade preferences still play an important role in this sector, these first tier suppliers are also responsible for distributing production in a way that maximizes the benefits of these preferences. They exert enormous influence over the next tier of suppliers and subcontractors (Gereffi, 1999 and Gereffi, 1997).

\section{Electronics}

In electronics, lead MNEs conduct most of the research and development (R\&D) along with higher value-added services such as sales, marketing and distribution, and the outsourcing of the manufacturing to global turn-key suppliers. MNEs exercise influence in internal markets through their ownership and marketing of the brand, and overall product development and design. An important feature of these global production systems has been the emergence of full-service contract manufacturing by first-tier suppliers (e.g. SCI, Solectron, Flextronics and Celestica).

With the exception of the personal computer industry, these first-tier full-service contract manufacturers are been predominantly located in the United States, but are now also emerging in Europe and parts of East Asia (e.g. Singapore). They coordinate bundles of discrete assembly activities (e.g. circuit board assembly) in different parts of the world, often in EPZs, and then undertake final product assembly. The product is customized to the needs of the lead MNE. They are also involved in the design of products and subcomponents for modular manufacturability, testing and after-sales service and repair and maintain strong ties with the lead MNE (Sturgeon, 2002). 


\section{Automobile}

There has been some restructuring underway in the global value chain in the automobile industry. Faced with increasing competition in the 1980's and 1990's, vehicle manufacturers in the United States and Europe reduced their in-house production levels and began to shift certain functions to their suppliers.

Today MNE manufacturers tend to concentrate on final assembly of the product and outsource the manufacture of components, including the sub-assembly of components to first-tier suppliers. The MNE provides overall specification and information about the interface of a particular component with the rest of the car and a first-tier supplier then either customizes a component or designs a solution using its own technology. First-tier suppliers have shifted to producing and installing complete units (e.g. dashboards, seats, brake-axle suspension etc) rather than individual components. While they are relatively dependent on a few MNEs for their orders, they assume responsibility for managing the rest of the chain, sourcing sub-components from second- and third-tier suppliers, overseeing the quality of the sub-assembly operations and integrating these intermediate products into the modular units they produce for these MNEs.

Technology-enabled integration of logistics and quality systems between MNEs and firsttier suppliers in the context of just-in-time production methods have led to much closer relationships between them. However, the auto industry remains highly concentrated and this close co-operation does not reduce the exercise of power in internal markets by MNEs (Humphrey and Memedovic 2003). There has also been significant consolidation among first-tier suppliers in recent years. Some have evolved into global mega-suppliers with world-wide reach and have become MNEs in their own right. The result of this consolidation is that the design activities, where most of the rents are increasingly to be found, lie in the hands of a decreasing number of component manufacturers (Kaplinsky, 2000).

Beyond these larger suppliers, second-tier suppliers are often located in only one market and work off designs given either by MNEs or global mega-suppliers. Still another step removed are third-tier suppliers who essentially feed basic products into the supply chain and are not called upon to provide any more than rudimentary skills, and which compete with one another essentially on the basis of price.

\section{Agro-commodities}

In agro-commodities, the nature of the supply chains is very different, depending on the commodity, the particularities of the domestic market, and the practices that have developed over time among commodity suppliers in different parts of the world. But some global production systems are emerging in agro-commodities as traders and producers attempt to add more value to the commodity.

In the international coffee, cocoa and sugar trade, for example, the liberalization of international markets, industrial concentration and improved processing technologies, has transformed the supply chain. International traders now also provide enhanced services to the brands such as customer inventory management and quality certification.

Food sales in developed countries are also becoming more concentrated among a few large supermarket retailers. For example, in the United Kingdom, the top four retailers account for $75 \%$ of all food sales. Yet despite this market concentration, competition has increased. Supermarkets responded by increasing the value of fresh produce by providing produce that required no washing or preparation prior to cooking, offering a consistent year-round supply of seasonal vegetables and emphasizing quality. This transformed the global supply chain in horticulture. Whereas fresh vegetables had traditionally been bought and sold in wholesale markets, supermarkets began to bypass wholesale markets and buy directly from producers and in this way were able to more explicitly coordinate a global value chain. 
This enabled them to gain some control over quality, preparation and packaging, and ensure traceability and adherence to food standards.

The intermediaries between these supermarkets and the developing country smallholder, large contract farmer, or plantation are the exporters (responsible for processing, packaging and transport) and importers (responsible for storage, checking produce, repackaging and labeling). These intermediaries usually have an exclusive arrangement for trade between their two countries (i.e. an exporter in Kenya will only sell to one importer in the UK). While the importer may in turn supply to a number of different supermarkets, the introduction of 'category managers' among importers, who are asked to focus on supplying a smaller range of products in larger volumes, means that they now assume some of the coordination and management services once performed by the supermarkets. This has strengthened their position in the global value chain and led to the consolidation of supply chains into different categories (Dolan, C. and Humphrey, J. 2004).

\section{ITES, Commerce, financial, professional and IT services}

The ICT revolution and liberalization of trade and FDI has opened up the possibility for trade in services. As more and more service functions become tradable, global production systems are beginning to emerge in services sectors such as such tourism, finance, commerce, professional and information technology (IT). For example Dossani and Kenney (2004) document the emergence of a global production system in the insurance industry.

The outsourcing of information technology-enabled services (ITES) is also becoming more prevalent across all global production systems (services and manufacturing). These include a myriad of business process services that a firm undertakes to service its employees, vendors and customers such as human resources, accounting, auditing, customer care, telemarketing, tax preparation, claims processing, document management and data entry (back office administrative services).

The emergence of global production systems in the services sectors and increased outsourcing of ITES in all global production systems provided important opportunities for small and medium sized firms in developing countries. A number of new mid-tier enterprises in developing countries have been set up for the sole purpose of offering these intermediate services to foreign firms (Dossani, and Kenney, 2004).

It is worth noting that the service components of the global value chain that are functionally integrated within global production systems, such as software development, investment banking, legal research and translation, all require higher levels of skill and analytical ability (UNCTAD, 2004). The fact that the outsourcing of these jobs from developed to developing countries is of higher skill content (as compared to the low-skilled assembly jobs traditionally 'transferred' in these global production systems) has important policy implications for labour market policy in industrialized and developing countries alike. 


\section{Bibliography}

Acemglu, D. 2002. "Technical change, inequality and the labour market", Journal of economic literature, Vol. 40, No. 1, pp $7-72$.

Amsden, A. 2001. The Rise of "the Rest": Challenges to the West from Late-Industrializing Economies. Oxford, Oxford University Press.

Arndt, S. and Kierzkowski, H. (eds.) 2001. Fragmentation: New Production Patterns in the World Economy, Oxford University Press.

Barrientos, S. Kabeer, N. and Hossain, N. 2004. "The gender dimension of the globalization of production”, Policy Integration Working Paper No. 17, ILO, Geneva.

Brown, D. 2001. "Labour standards: Where do they belong on the international trade agenda?"; Journal of Economic Perspectives, Vol. 15. No. 3, pp 89 - 112.

Brown, D., Deardorff, A. and Stern, R. 2002. "The effects of multinational production on wages and working conditions in developing countries", paper presented at CEPR/NBER/SNS Conference, Stockholm, May 2002.

Borga, M. and Zeile, W. 2002. "Foreign Outsourcing and the Intrafirm Trade of U.S. Multinational Companies", mimeo.

Buckley, P. and Casson, M. 1976. The Future of the Multinational Enterprise, Macmillian: London.

Campa, J. and Goldberg, L. 1997. "The Evolving Export Orientation of Manufacturing Industries: Evidence from Four Countries”, NBER Working Paper no. 5919, February 1997.

Caves, R. 1971. "International Trade, International Investment and Imperfect Markets", In Scherer, F.M. (ed.) Monopoly and competition policy, Aldershot, U.K., Elgar.

Castells, M. 1996. The Information Age: Economy, Society and Culture: The rise of the network society, Vol 1, Blackwell.

Dolan, C. and Humphrey, J. 2004. "Changing governance patterns in the trade in fresh vegetables between Africa and the United Kingdom", Environment and Planning, vol 36, pp 491 - 509

Dossani, R. and Kenney, M. 2004. "The next Wave of Globalization? Exploring the Relocation of Service Provision to India", Berkley Roundtable on the International Economy (BRIE), Working Paper 156.

Dicken, P. 1998. Global Shift: Transforming the World Economy. Guilford Press, New York.

Dunning, J. 2000. "The eclectic paradigm as an envelope for economic and business theories of MNE activity", in International Business Review, 9, pp 163 - 190.

Elliot, K. and Freeman, R. 2003. Can Labor Standards Improve Under Globalization? Institute for International Economics, Washington D.C.

Feenstra, R. 1998. "Integration of trade and disintegration of production in the global economy", The Journal of Economic Perspectives, 12 (4), pp $31-50$.

Feenstra R. and Hanson, G.,1999. "Productivity measurement and the impact of trade and technology on wages: Estimates for the U.S., 1972 - 1990" Quarterly Journal of Economics, 114 (3), pp 907 -940 .

Feenstra, R. and Hanson, G. 2001. "Global Production Sharing and Rising Inequality: A Survey of Trade and Wages", NBER Working Paper no. 8372.

Gereffi, G. 1994. "The organization of buyer-driven global commodity chains: How US retailers shape overseas production networks" in Gereffi, G. and Korzenieweiz, M. (eds.) Commodity chains and global capitalismWestport, CT: Praeger, pp $95-122$.

Gereffi, G. 1997. "Global Shifts, Regional responses: Can North America meet the full-Package challenge?”, Bobbin 39 (3), pp 6-31. 
Gereffi, G. 1999. "International trade and industrial upgrading in the apparel commodity chain" Journal of International Economics 48 (1), June 1999, pp 37 - 70.

Gereffi, G. 2002. The International Competitiveness of Asian Economies in the Apparel Commodity Chain, ERD Working Paper, February 2002.

Gerreffi, G. Humphrey, J. and Sturgeon, T. 2003. The Governance of Global Value Chains: An analytical Framework. Forthcoming in Review of International Political Economy, November, 4, 2003 .

Gereffi, G. and Memedovic, O. 2003. "The Global Value Apparel value chain: What prospects for upgrading by developing countries", UNIDO, Sectoral Studies Series, Vienna.

Gereffi, G., 2004. "The Global Economy: Organization, Governance and Development" in Smesler, N. and Swedberg, R. (Eds.) Handbook of Economic Sociology, Princeton University Press and Russell Sage Foundation.

Gereffi, G,. and Mayer, W. 2004. "The Demand for Global Governance: A Co-Evolutionary Theoretical Framework", Terry Sanford Institute of Public Policy Working Papers Series, SAN04-02, September 2004.

Ghose, A. 2003. Jobs and Incomes in a Globalizing World, International Labour Office, Geneva

Harrison, A. 2004. "Moving Up or Moving Out? Anti-Sweatshop Activists and Labor Market Outcomes", NBER Working Paper 10492.

Hanson, G. 2000. "Should Countries Promote Foreign Direct Investment", G24 Working Paper, UNCTAD, Geneva.

Hummels, D. Ishii, J. and Yi, K., 2001. The nature and growth of vertical specialization in world trade. Journal of International Economics 53, pp 75 - 96.

Humphrey, J. and Memedovic, O. 2003. "The Global Automotive Industry value chain: What prospects for upgrading by developing countries", UNIDO, Sectoral Studies Series, Vienna

Humphrey, J. and Schmitz, H. 2002. "Developing firms in the world economy: governance and upgrading in global value chains", INEF Report, No.61, Duisburg: Institut für Entwicklung und Frieden der Gerhard-Mercator-Universität Duisburg. http://inef.uniduisburg.de/page/PublSerien.html

Humphrey, J. 2004. "Upgrading in Global Value Chains", Policy Integration Working Paper No. 28, ILO, Geneva.

Hymer, S. 1968. "The large multinational "corporation": and analysis of some motives for the international integration of business' in Casson, M. (eds) 1990, Multinational Corporations, Edward Elgar, Aldershot.

ICFTU, 2004. Behind the brand names: working conditions and labour rights in export processing zones, ICFTU, Brussels.

ILO,1998. ILO Declaration on Fundamental Principles and Rights at Work and its Follow-up, ILO, Geneva.

ILO, 2003. Employment and social policy in respect of export processing zones (EPZs), GB. 286/ESP $/ 3,286^{\text {th }}$ Session, Geneva, March 2003.

ILO, 2004. A Fair Globalization: creating opportunities for all, Report of the World Commission on the Social Dimension of Globalization, Geneva.

Javorcik, B. and Spatareanu, M. 2004. Do investors care about labour market regulations? World Bank Policy Research Working Paper, 3274, Washington D.C.

Kaplinsky, R. 2000. Globalization and Unequalization: What can be learned from Value Chain Analysis? Journal of Development Studies, Vol 37, No.2, December 2000.

Kaplinsky, R. and Morris, M. 2002. "The globalization of product markets and immiserisiing growth: Lessons from the South African Furniture Industry". World Development, 30(7): 1159-1177. 
Kaplinsky, R. 2004. Sustaining income growth in a globalising world: The search for the $N^{\text {th }}$ rent, Mimeo, Institute for Development Studies, Sussex.

Krugman, P. 1995. "Growing world trade: causes and consequences", Brookings Papers on Economic Activity, Vol. 1, pp 327 - 377.

Krugman, P. 2000. “Technology, trade and factor prices”, Journal of International Economics, Vol. 50, No. 1, pp 51 - 71 .

Kucera, D. 2001. "The effects of core workers' rights on labour costs and FDI: Evaluating conventional wisdom", International Institute for Labour Studies Discussion Paper D/130/2001, International Labour Office, Geneva.

Kucera, D. and Sarna, R. "How do trade union rights affect trade competitiveness?", Policy Integration Working Paper No. 39, International Labour Office, Geneva.

Lund, F. and Nicholson, J. 2004, "Chains of production, ladders of protection: social protection for workers in the informal economy", Vol. 1. World Bank, Washington. Milberg, W., 2004, "The changing structure of international trade linked to global production systems: what are the policy implications?", Policy Integration Working Paper No. 33, International Labour Office, Geneva.

Moran, T. 2001. "Parental supervision: The new paradigm for foreign direct investment and development", Policy Analyses in International Economics No. 64, Institute for International Economics, Washington, D.C.

Nolan, P., Sutherland, D. and Zhang, J. 2002. "The challenge of the global business revolution", Contributions to Political economy, 21, pp 91 - 110

Nordås, H. 2004. "The Global Textile and Clothing Industry post the Agreement on Textiles and Clothing", WTO Discussion Papers, No. 5, World Trade Organization, Geneva.

OECD, 1996, Trade, employment and labour standards: a study of core workers' rights and international trade, OECD Publications, Paris.

OECD, 2001, New Patterns of Industrial Globalization: Cross-border mergers and acquisitions and strategic alliances, OECD Publications, Paris.

Oman C. 2000, Policy competition for foreign direct investment: A study of competition among governments to attract FDI, OECD Development Centre, Paris.

Oxfam, 2004, Trading away our rights: Women working in global supply chains, Oxfam International, www.maketradefair.com.

Penfold, B. 2003, "Labour and Employment Conditionalities and Foreign Direct Investment: A Review of Conditions on Public Support for FDI", working paper prepared for ILO Department on Multinational Enterprises, Geneva.

Polaski, S. 2004a, "Protecting Labor Rights through Trade Agreements: An analytical guide", Journal of International Law and Public Policy, July 14, 2004.

Polaski, S. 2004b, 'Cambodia blazes a new path to economic growth and job creation', Carnegie Papers, No. 51, October 2004, Carnegie Endowment for International Peace.

Porter, M. 1985, Competitive Advantage, New York: Free Press.

Powell, W. 1990, "Neither market nor hierarchy: Network forms of organization". Research in Organizational Behavior 12, pp 295 - 336.

Sable, C. and Piore, M. 1984. The Second Industrial Divide: Possibilities for Prosperity, New York: Basic Books.

Sabel, C. O'Rouke, D. and Fung, A. 2000, "Ratcheting Labor Standards: Regulation for Continuous Improvement in the Global Workplace", Mimeo. 
Slaughter, M. 1998. "International Trade and Labour Market Outcomes: Results, Questions and Policy options", The Economic Journal, 108 (450) pp 1452 - 1462.

Steiert, R. (IMF) and Hellmann, M. (IFBWW), 2004. Mimeo.

Sturgeon, T. 2002, "Modular production Networks a new American model of Industrial Organization", Industrial Organization and Change, Vol. 11, No. 3, pp. 451 - 496.

UNCTAD, 2002a, World Investment Report, Geneva.

UNCTAD, 2002b, Trade and Development Report, Geneva.

UNCTAD, 2003, Trade and Development Report, Geneva.

UNCTAD, 2004, World Investment Report, Geneva.

Venables, A. 2002. "Vertical Specialization", mimeo, ILO, Geneva.

Vernon, 1971, Sovereignty at Bay: The Multinational spread of U.S. Enterprises. New York: Basic Books.

Yeats, A. 1998. "Just how big is global production sharing?” Policy Research Paper, 1871, World Bank

Yi, K. 2003. Can vertical specialization explain the growth of world trade? Journal of Political Economy, Vol. 111 (1), 52 - 102.

Wood, A. 1994, North - South trade, employment and inequality, Oxford, Clarendon Press.

Wood, A. 1995, "How trade hurt unskilled workers", in Journal of Economic perspectives, Vol. 9 No. 3, pp $57-80$.

World Bank, 2003, Global Economic Prospects, Washington D. C. 


\section{Policy Integration Department Working Papers prepared for the World Commission on the Social Dimension of Globalization}

No. 16 International finance: Meeting the needs of people in developing countries, José Guilherme Almeida dos Reis

No. 17 The gender dimensions of the globalization of production, Stephanie Barrientos, Naila Kabeer and Naomi Hossain

No. 18 Social exclusion in the context of globalization, Jan Breman

No. 19 Gender and globalization: A macroeconomic perspective, Çağatay Nilüfer and Ertük Korkurt

No. 20 Globalization, social exclusion, and work: with special reference to informal employment and gender, Marilyn Carr and Martha Chen

No. 21 Resources for social development, Anthony Clunies Ross

No. 22 Does the new international trade regime leave room for industrialization policies in the middle-income countries?, Alisa DiCaprio and Alice Amsden

No. 23 Social dimension of globalization in Latin America: Lessons from Bolivia and Chile, Alvaro García Hurtado

No. 24 Globalization: Social impact and policy actions: A partly annotated bibliography, Bernhard Gunter and Rolph van der Hoeven

No. 25 The social dimension of global production systems: A review of the issues, Susan Hayter

No. 26 Reforming global economic and social governance:

a critical review of recent programmatic thinking, Jeremy Heimans

No. 27 Corporate social responsibility: An issues paper, Michael Hopkins

No. 28 Upgrading in global value chains, John Humphrey

No. 29 Implications of globalization and economic restructuring for skills development in Sub-Sahara Africa, Richard K. Johanson

No. 30 The outcome and impact of the main international commissions on development issues, Frédéric Lapeyre

No. 31 Globalization and structural adjustment as a development tool, Frédéric Lapeyre

No. 32 Globalization and perceptions of social inequality, Malte Lübker

No. 33 The changing structure of trade linked to global production systems:

What are the policy implications?, William Milberg

No. 34 Corporate social responsibility: An overview of principles and practice, Jill Murray

No. 35 Inclusive development strategy in an era of globalization, Ignacy Sachs

No. 36 Social consequences of the globalization of the media and communications sector: Some strategic considerations, Seán Ó. Siochrú

No. 37 Globalization, history and international migration - A view from Latin America, Andrés Solimano

No. 38 Towards a different kind of globalization, or how the anti-globalizers view the world, Gijsbert van Liemt 